\title{
THE STATE OF GREEK BANKS WITHIN EUROSYSTEM
}

\author{
Eleni Koletsa ${ }^{169}$
}

https://doi.org/10.31410/itema.2018.413

\begin{abstract}
This paper presents the profitability of the Greek banks for the years 2010-2015 and the way they are stated as a member of the Euro system. First of all, we examined the liquidity of Greek Banks and how they used the Euro system funding. Taking into consideration the bank assets and liabilities we examined how the Greek banking groups presented profits for the year 2016, after a series of loss-making years. The results of this paper may help us to understand better the factors that lead to a restoration of profitability, the stabilization of an economy and the re-establishment of confidence in the banking system.
\end{abstract}

Keywords: Profitability, Greek Banks, efficiency, Euro system

\section{Introduction}

$\mathrm{I}$

$\mathrm{n}$ the current financial environment is rendered necessary the existence of financial corporations, as their role in the configuration of money offer is decisive. The form of what is activated in an economy is related with the institutional frame, the degree of markets release and the degree of economy growth. Main representative of financial corporations are the credit institutions (banks). Nowadays, after some basic changes in the European and International financial and corporate world, banks have obtained multiple activities and they can activate in the offer of all products and services of financial world. In general, the banking world is characterized by a rapid change. The strategic priority has shifted away from growth and size alone towards a greater emphasis on profitability, performance and "value creation" within the banking corporation. Banks, traditionally, have a major role in an economy, as they act as intermediaries between depositors and borrowers (Serletis and Mishkin, 2010).

The difference between banks and the other financial corporations is that they provide deposit and loan products. Banks deal with liabilities' management and lend money, in order to create bank assets. Otherwise, it can be considered that banks are funded by deposits, or other liabilities. In the modern banking systems, there exists an enormous range of special banks, that is focused in specialized markets, and general banks, which offer a wide spectrum of banking and other financial products, differentiated as accounts of deposits, loans, services of real estates, Stock Exchange market and the Insurance (Heffernan Shelagh, 2006)

\section{A brief literature review regarding the Greek Banking System}

The credit institutions had be founded as one of the structural elements of each economy and through the operations that they carry out, participate actively, supporting the institutions of developmental process. The first credit institution that was founded and functioned in Greece was Ioniki Bank (1834) and followed the National Bank of Greece, which was founded in.

${ }^{169}$ SWU “Neofit Rilski”- Blagoevgrad, Department of Finance and Accounting, Bulgaria 
The structural changes in the Greek banking system began in the early 1980s when the role of Bank of Greece, in the conduct almost independent monetary policy was strengthened (Law 1266/1982). Karatza's report in 1987 placed the ground for an extensive process of market deregulation, with the motive of the internationalization of competition and the institution financial services in a united European market. After this report, financial markets were operating their controls more loosely in the middle of decade 1990. Bryant, Garganas and Tavlas (2001) named the three factors that affected the reconstruction of the Greek banking sector. According to them, the convergence with European standards, the competition and privatization led the banking system to leave its bureaucratic character.

The most important changes had been done in the determination of interest rates, which it became more liberated, was the released movement of the short-term and long-term capital and the rule repression on the operations of the credit institutions. (Noulas, 1999). The Amplified cross-border competition had allowed banks from other EU countries to do business in Greece. As a result, the domestic banking system deals the competition both with markets and the other counterparts. The development of the financial markets in Europe (through bonds, derivatives, equities) permits corporate and private customers to select from a wide variety of alternative financial instruments (Eichengreen and Gibson, 2001).

Since then, the credit institutions became from traders and editors of money to the most important collectors and distributors of financing information in the economic system. The institutional operational frame of banks is variable while the institutions are obliged to read just according to the institutional changes that the enterprising environment imposes. As a consequence, the banks function much more with private economic criteria having advanced progressively by their initial nature, shaping different profile relatively as much with their mission and their operation, as with the organizational structure and their strategy. It is characterized as universal banking. (Aggelopoulos P. 2008).

Nowadays, the basic frame of foundation and operation of Greek credit institutions is implemented according to the regulations of Basel Committee on Banking Supervision (Basel Accords II and III). Credit Institutions are legally defined as "an undertaking whose business is to receive deposits or other repayable funds from the public and to grant credits for its own account"» (Glykas M., Xirogiannis G., Staikouras C., 2006)

\section{Greek Bank's activity in Southeastern Europe (SEE)}

Greek banks in the SEE10 mainly activate in three countries, that is to say Romania, Cyprus and Bulgaria. The assets of Greek banking groups raised to 34.3 billion in June 2016, increased at $1,8 \%$ of December 2015 and represented the $11 \%$ of their assets. However, there are subsidiaries and branches in the following SEE countries: Albania, Bulgaria, Cyprus, FYROM, Romania, Serbia and Ukraine. 
Figure 1. Assets of the Greek banking groups in SEE

Assets of the Greek banking groups in SEE

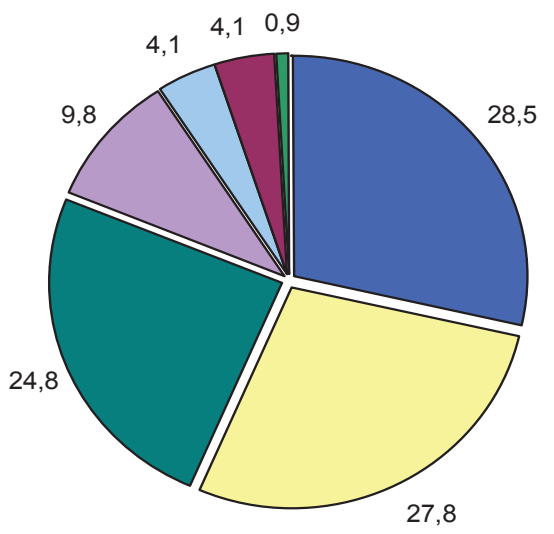

(Source: Bank of Greece)

The first semester of 2016, the international enterprising activity of Greek banks had positive contribution in their results, with pre - taxes profits of a height of $€ 129$ million (against damage at the first half of 2015) that emanates mainly from Bulgaria (43,4\%), Cyprus $(28,4 \%)$ and FYROM (17,2\%). The enterprises in Albania and Ukraine were forfeiting. The profitability contributed an increase in proper funds compared to the first semester of 2015.

There are positive prospects for the profitability and the quality of asset in the activities of Greek banks, taking into account the improvement of developmental prospects of EU countries and the exit of Cyprus from the Program of Economic Adjustment. In this frame, Greek banks can investigate further the strategic occasions in South-eastern Europe, according to the directions given by the European Commission.

\section{Liquidity over Euro system funding}

During 2016, Greek banks improved their liquidity achieving a significant reduction in their dependence on the Euro system

Specifically:

- The overall dependence of the Greek banking system on the Euro system declined in December 2016 to 66.6 billion euro's, down 47.3\% compared to June 2015 ( $€$ 126.6 billion) and 38\% over December 2015 ( $€ 107.5$ billion), and

- The use of ELA ${ }^{4}$ has been limited in December 2016 to EUR 43.7 billion, down by $49 \%$ compared to the previous year, in June 2015 (EUR 86.8 billion) and by $37 \%$ in December 2015 (68.9 billion).

As it mentioned, developments led to important reduction of dependence of banks from the ELA (Emergency Liquidity Assistance), which amounted in $€ 46,3$ billion in October 2016, from $€ 68,9$ billion in the end of 2015 . These developments were the result of the replacement 
of the liquidity from a refinancing through its monetary policy operations of Euro system, following the ECB's (European Central Bank) Governing Council Decision.

In December 2016, the liquidity of the Greek banking system by Euro system (ECB and ELA) amounted to $55 \%$ compared to the rest deposits of domestic households and businesses. In June 2014, the corresponding figure stood at $27.6 \%$ and in June 2015 to $103.6 \%$.

Figure 2. Liquidity to Loans from Euro system

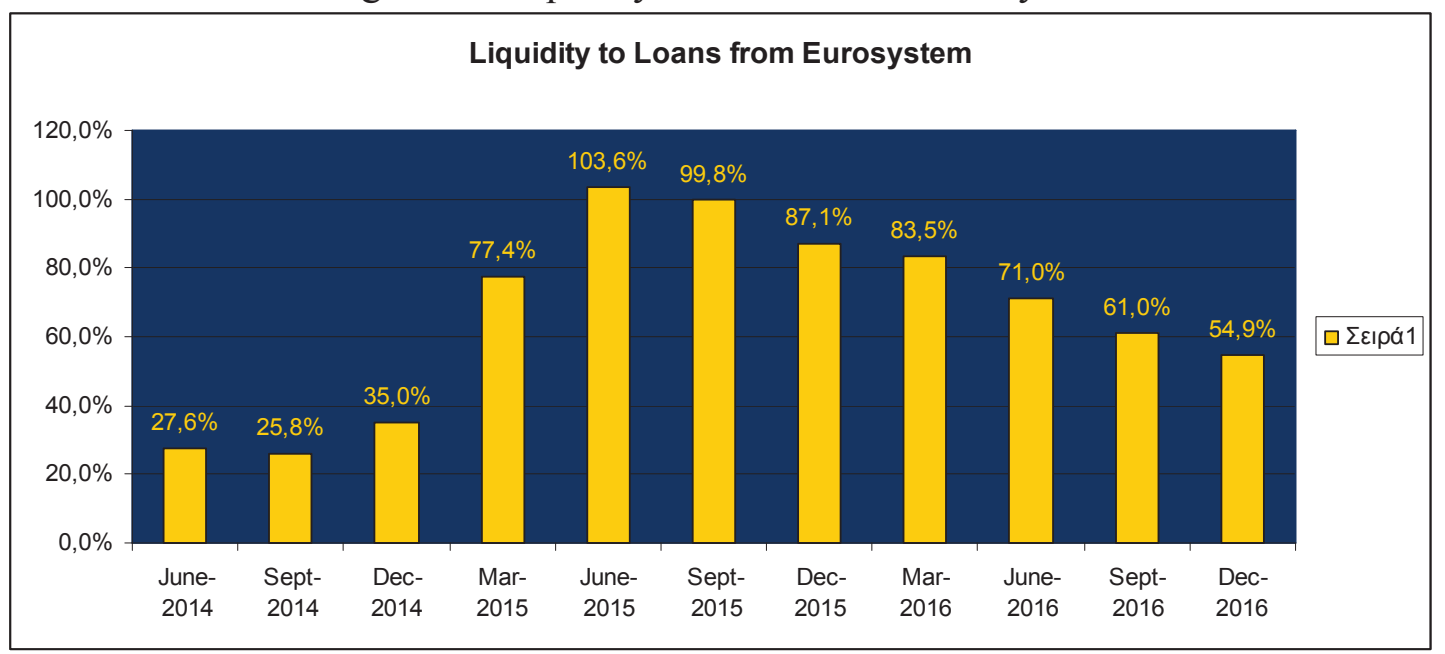

(Source: Bank of Greece)

Despite the significant outflows of deposits in the first half of 2015, from June 2015, as a result of the stabilization of deposits and the deleveraging of banks' assets, the ratio of loans to deposits declined gradually by 13 percentage points and even more noticeably from 16 percentage points, taking into account the increased forecasts for that period.

Figure 3. Loans to Deposits

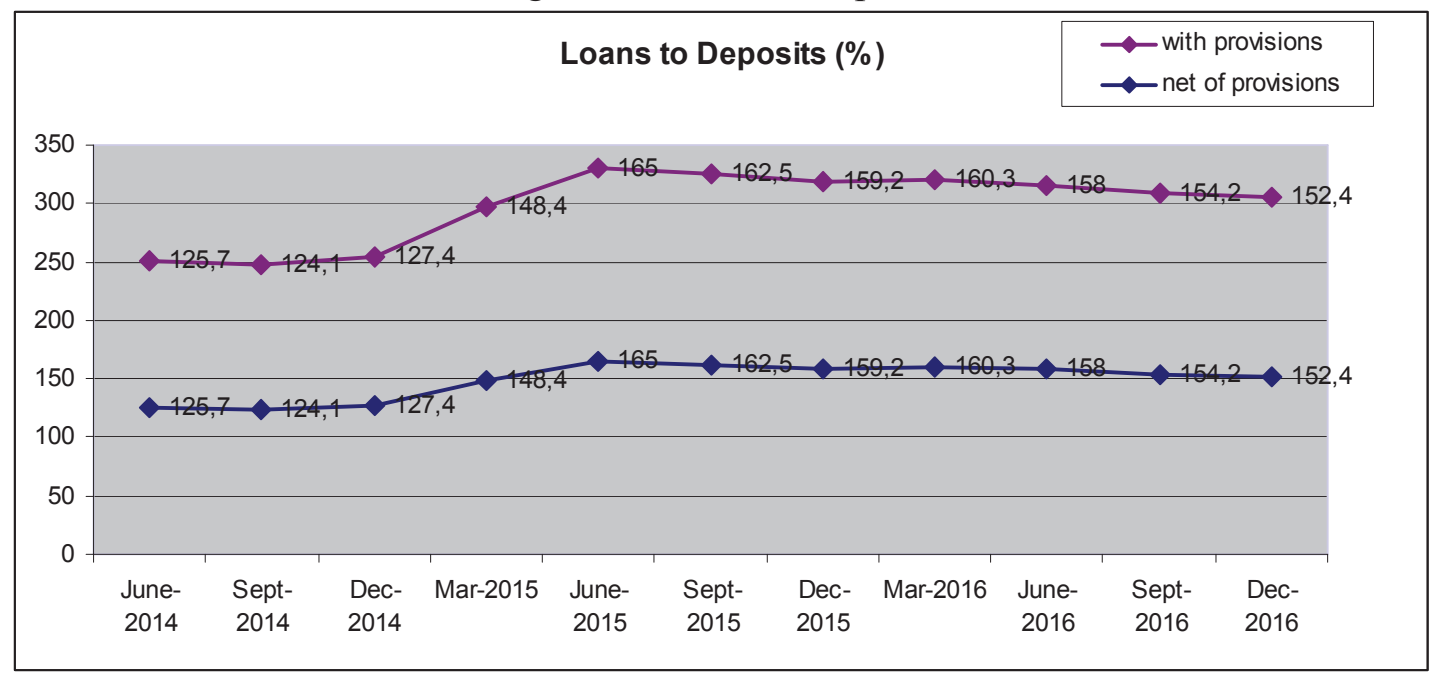

(Source: Bank of Greece)

The following table shows the development of ratio of loans to deposits, that continues being enough higher than the average for the smaller banks. With regard to the interbank market, the access in the financing via interbank repos is increased from September 2015. 
Figure 4. Loans to commercial bank deposits

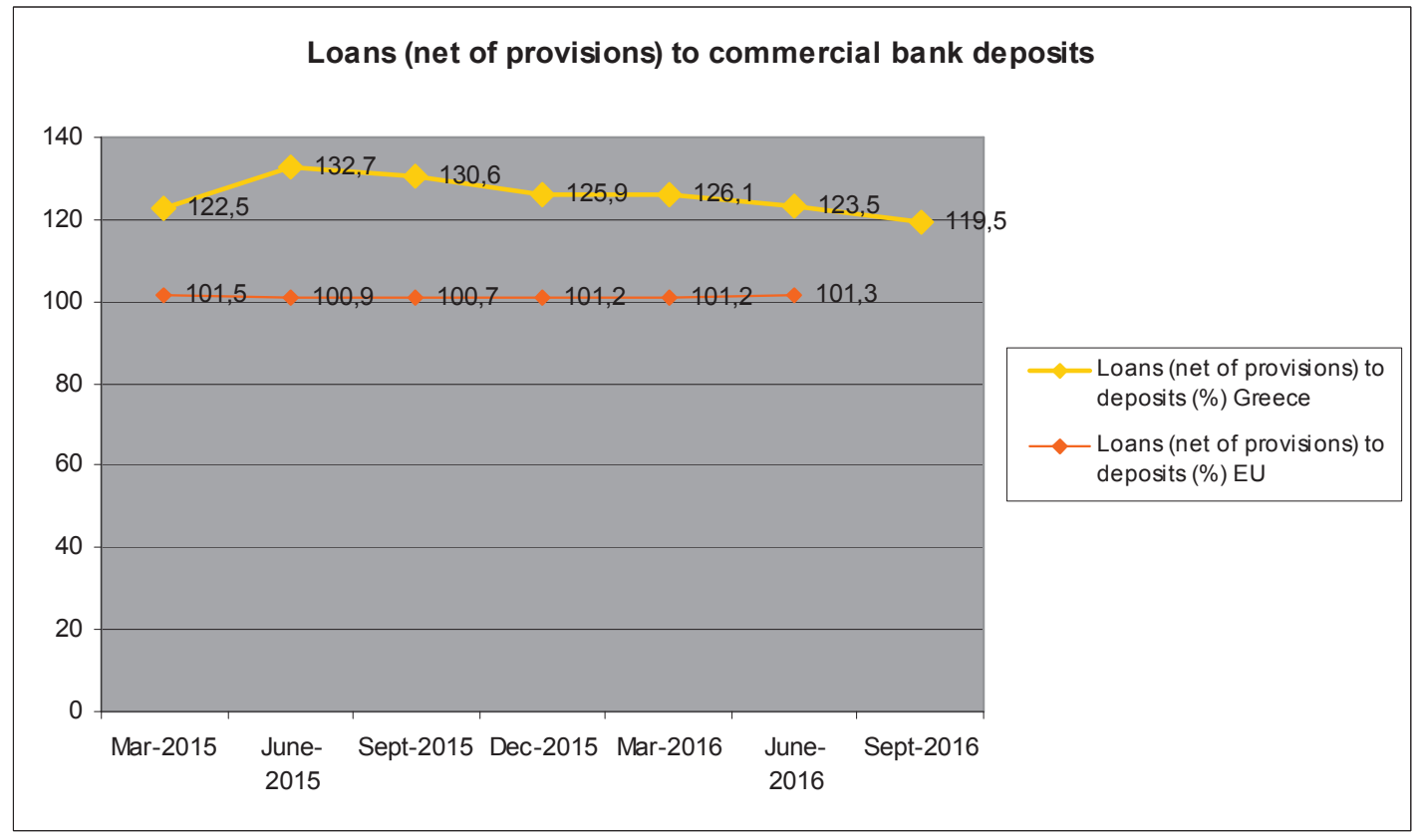

(Source: Bank of Greece)

\section{Structure of Assets and Liabilities}

In the first semester of year 2016 the decrease of borrowing from the Euro system in combination to the sale of National Bank's subsidiary Finasbank caused the reduction of total asset of Greek banking groups at 33 billion of Euros (312 billion of Euros from 345 billion that were in the end 2015).

Table № 1. Structure of assets and liabilities of the Greek commercial banking groups

\begin{tabular}{|c|c|c|c|c|c|}
\hline \multicolumn{6}{|c|}{$\begin{array}{l}\text { Structure of assets and liabili } \\
\text { (amounts in EUR millions) }\end{array}$} \\
\hline \multicolumn{2}{|c|}{2015} & \multicolumn{2}{|c|}{ June- 2016} & \multicolumn{2}{|l|}{ Change } \\
\hline \multicolumn{2}{|c|}{ Assets } & \multicolumn{2}{|c|}{$\%$} & \multicolumn{2}{|l|}{$\%$} \\
\hline Loans & 185,094 & 53.5 & 181,950 & 58.2 & $-3,144$ \\
\hline Bonds\& Equities & 72,262 & 20.9 & 63,306 & 22.2 & $-2,955$ \\
\hline $\begin{array}{l}\text { Equity } \\
\text { participations, } \\
\text { Assets \& Others }\end{array}$ & 71,123 & 20.6 & 43,680 & 14.0 & $-27,443$ \\
\hline $\begin{array}{l}\text { Claims on credit } \\
\text { institutions }\end{array}$ & 7,830 & 2.3 & 8,432 & 2.7 & 602 \\
\hline $\begin{array}{l}\text { Cash and } \\
\text { reserves at the } \\
\text { central bank }\end{array}$ & 9,460 & 2.7 & 9,042 & 2.9 & -418 \\
\hline Total & 345,769 & 100.0 & 312,411 & 100.0 & $-33,358$ \\
\hline \multicolumn{2}{|l|}{2015} & \multicolumn{2}{|c|}{ June- 2016} & \multicolumn{2}{|l|}{ Change } \\
\hline \multicolumn{2}{|l|}{ Liability } & \multicolumn{2}{|c|}{$\%$} & \multicolumn{2}{|l|}{$\%$} \\
\hline Customer deposits & 147,073 & 42.5 & 147,374 & 47.2 & 301 \\
\hline $\begin{array}{l}\text { Liabilities to } \\
\text { credit institutions }\end{array}$ & 115,442 & 33.4 & 103,554 & 33.1 & $-11,889$ \\
\hline
\end{tabular}




\begin{tabular}{|l|c|c|c|c|c|}
\hline Own funds & 36,925 & 10.7 & 36,699 & 11.7 & -226 \\
\hline Bank bonds & 1,905 & 0.6 & 1,782 & 0.6 & -123 \\
\hline Others & 44,424 & 12.8 & 23,002 & 7.4 & $-21,421$ \\
\hline Total & $\mathbf{3 4 5 , 7 6 9}$ & $\mathbf{1 0 0 . 0}$ & $\mathbf{3 1 2 , 4 1 1}$ & $\mathbf{1 0 0 . 0}$ & $\mathbf{- 3 3 , 3 5 8}$ \\
\hline
\end{tabular}

(Source: Bank of Greece)

The decisive factors which contributed in this reduction were:

a) The reduction of the net outstanding amount of loans at 3 billion of Euros,

b) The fall of the bond and equity valuation at 3 billion Euros, and

c) The reduction of other assets at 27 billion Euros because of the sale of foreign subsidiaries of Greek banks, mainly the sale of Finansbank from the National Bank.

At the examined period, the most important changes in the structure of asset were the increase of loans as percentage of total of assets in 58,2\% on 30 June 2016, from 53,5\% in December 2015 , because the fall of total asset and other that failed as a percentage of total asset in $14 \%$ in 30 June 2016, from 20,6\% in 31 December 2015.

Figure 5. Structure of Assets

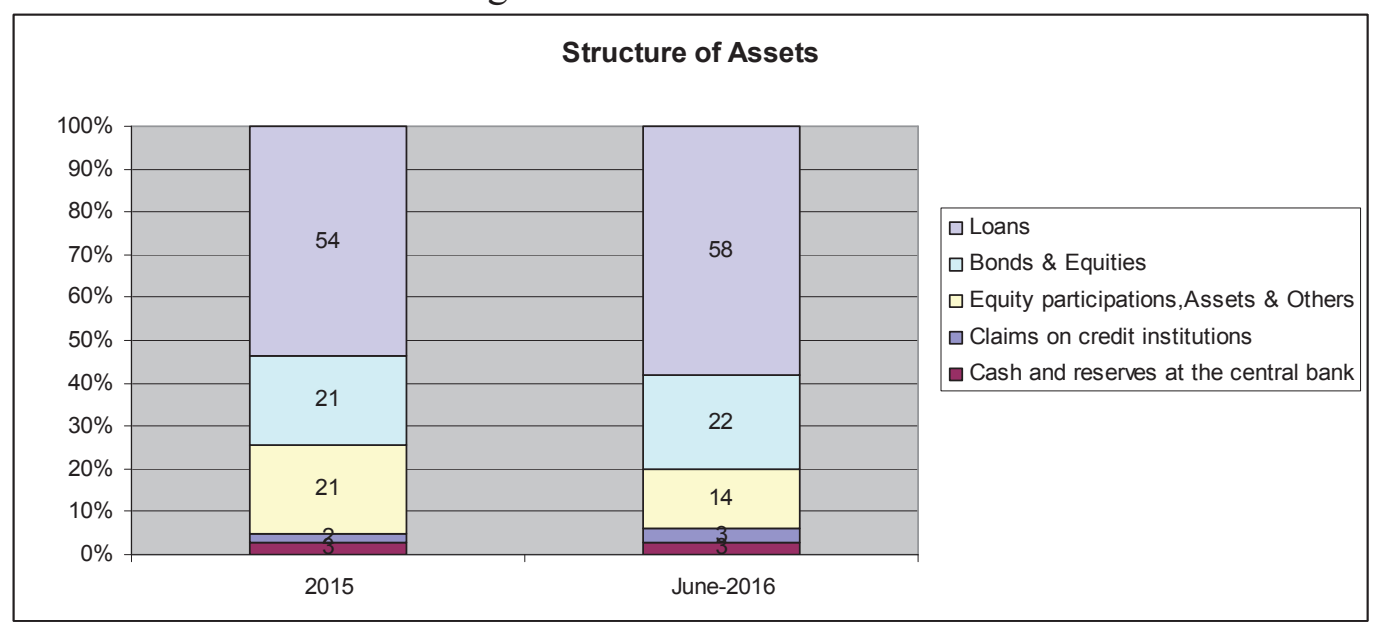

(Source: Bank of Greece)

About total liabilities, there is a remarkable growth. The change of liabilities in credit institutions at 12 billion Euros, as resulting of the reduction of lending by Euro system of 20 billion Euro at 6 billion Euro, and an increase of 8 billion in other liabilities to credit institutions. The further reduction of liabilities of 21 billion euro's was caused from the sale of Finansbank. There are noted some other structure changes such as the increase of the customers' settlement as a percentage of total obligations' reduction (47.2\%) and the other liabilities as a percentage of total liabilities $(7.4 \%)$. 
Figure 6. Structure of Liabilities

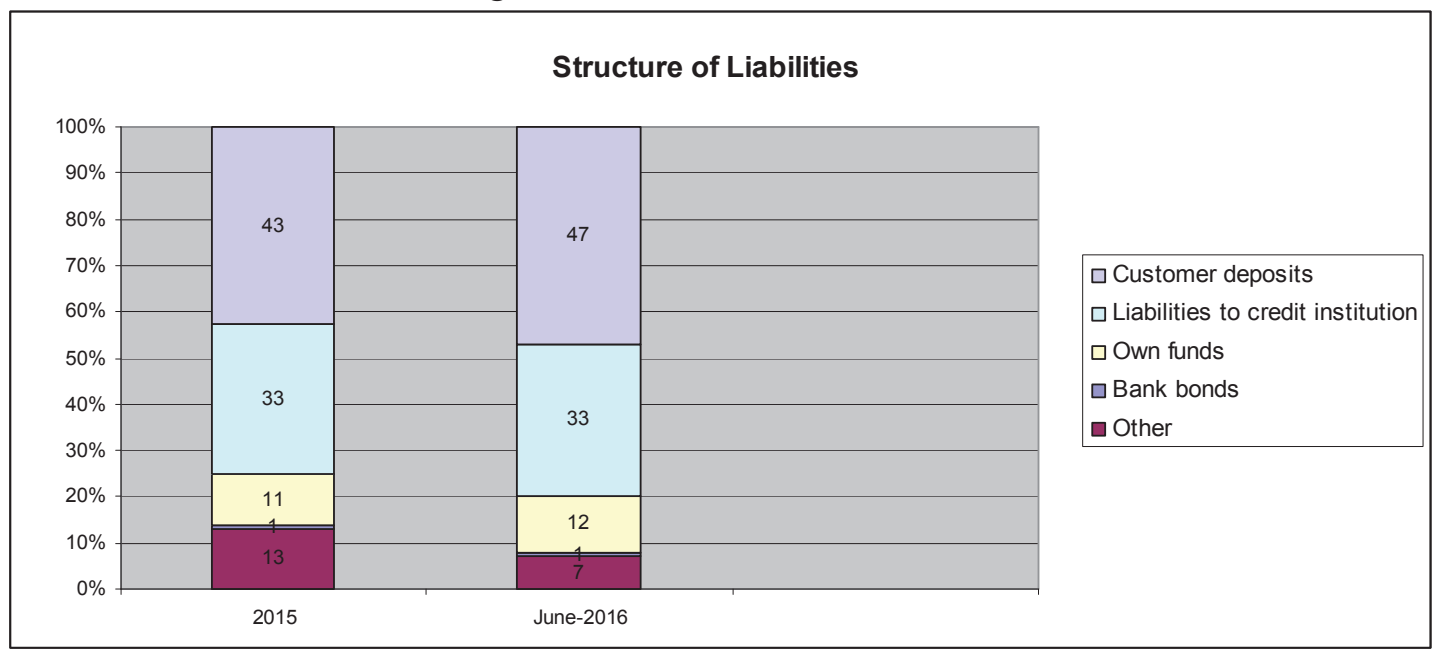

(Source: Bank of Greece)

It is pointed that an improvement in banking system's profitability for the first semester of 2016, where the pre-tax profits were 90 million Euros for the second-half of 2016, while there were losses of 7.5 billion Euros for the second half of 2015, and while the other income and expenses hasn't been affected a lot.

\section{Profitability}

During the period 2010-2015 Greek banks recorded damage before taxes in a total sum of 70, 3 billion euro. At the same time haven't been distributed dividends in the shareholders of Greek banks, while in September 2016 the accumulated forecasts of Greek banks amounted in 52 billions of euro's in individual base and in 57,1 billions of euro's in unified base.

In 2016 the Greek banking groups presented profits pre-taxes, after a series of loss-making years. After some quarters, the net income was shaped in a marginal level higher than these forecasts for the credit risk.

The profits pre-taxes of Greek banking groups in a nine-month level amounted in the 249 millions of Euros. The restoration of profitability was an improvement in operating results and an important reduction of forecasts of loan-loss. This tendency was continued until September of 2016 according to the elements of four basic banks.

Table 2. Profitability of Greek Banks

\begin{tabular}{|l|l|l|l|l|l|l|l|}
\hline Profitability of Greek Banks \\
\hline Million $\boldsymbol{€}$ & $\mathbf{2 0 1 0}$ & $\mathbf{2 0 1 1}$ & $\mathbf{2 0 1 2}$ & $\mathbf{2 0 1 3}$ & $\mathbf{2 0 1 4}$ & $\mathbf{2 0 1 5}$ & Sept. 2016 \\
\hline Profits pre-taxes & -823.8 & -3.142 & -9.137 & 1.388 & -7.278 & -11277 & 249 \\
\hline $\begin{array}{l}\text { Profits pre-taxes } \\
\text { and forecasts }\end{array}$ & 6.058 & 4.666 & 3.023 & 9.785 & 4.177 & 3.207 & 3.211 \\
\hline
\end{tabular}

(Source: Hellenic Bank Association)

Specifically, net interest income grew by $1.7 \%$ in comparison with the first half of 2015 due to a considerable decrease in interest expenses, which offset a fall in interest income. This decline in interest expenses is attributable to a reduction in the cost of Euro system financing, a gradual fall in interest rates on new deposits and a shift in the deposit base to current and saving accounts. Interest income was mainly affected by the shrinking of the loan book. As a result, 
the net interest rate margin improved in the first half of 2016 year-on-year (Table 1.8.) remaining well above the net interest rate margin of medium-sized banking groups in the EU.

Concretely, net income was increased at 1,7\% concerning the first semester of 2015 because of the important reduction of expenses of interest, which compensated the reduction of interest income. This reduction is owed in the reduction of Euro system's financial cost, in a progressive reduction of interest rates in the new deposits and the base of deposits in current accounts and accounts of saving.

Interest income was influenced mainly by the portfolio of loans. Consequently, the net interestrate margin was improved at the first semester of 2016.

Table 3. Profitability indicators in Greece Banking Groups

\begin{tabular}{|l|r|r|}
\hline \multicolumn{2}{|c|}{ Profitability indicators in Greece Banking Groups } \\
\hline Percentage \% & $\mathbf{2 0 1 5}$ & June-2016 \\
\hline & 2,1 & 2,4 \\
\hline Net Interest margin & 1,4 & 1,6 \\
\hline Operating costs/total assets & 55,1 & 52,5 \\
\hline Cost to income ratio & 2,6 & 0,6 \\
\hline Provisions for credit risk/total asset & 213,1 & 41,7 \\
\hline Provisions for credit risk/operating income & $-3,3$ & 0 \\
\hline Return of assets - ROA (after tax) & $-44,7$ & 0,3 \\
\hline Return on equity (after tax)
\end{tabular}

(Source: Financial statements of Greek banking groups, ECB Statistical Data Warehouse (SDW))

Operating costs were increased in the first semester of 2016, after they were decreased sufficiently in the latest years. Although, this was compensated by even more rapid increase of operating income. Net income was improved at the first half of 2016, as the ratio of effectiveness of Greek banks continues to be high.

The long-term prospects of profitability are connected unbreakably with the stabilization of Greek economy and the re-establishment of confidence in the banking system. Despite that, existing important provocations continue, mainly because of the completion of second review of the Third Economic Adjustment Programme for Greece, the achievement of reciprocally satisfactory result for the conceivability of public debt and the incorporation of Greek bonds in the program of ESF.

\section{Conclusions}

The main focus of the study was to examine the state of the Greek Banking system in Euro system during a period of financial and economic crisis. We presented the profitability for the years 2010-2016 and concluded that after a series of loss-making for the years 2010-2015 years, in 2016 Greek Banks presented profits pre-taxes. The net income was shaped in a marginal level higher than these forecasts for the credit risk. The profitability has been restored and the forecasts of loan-loss have been decreased. The long-term prospects of profitability are connected unbreakably with the stabilization of Greek economy and the re-establishment of confidence in the banking system. 


\section{References}

Angelopoulos, P. (2008) "Banks and monetary system" second edition, Stamoulis publications, Athens

Bryant, R. C., Garganas, N. C. and Tavlas, G. S. (2001), “Greece's Economic Performance and Prospects", Bank of Greece and the Brookings Institution, pp. 43-95

Glykas M., Xirogiannis G., Staikouras C., (2006), "Organization and administration of financial institutions", Papazissis publications, Athens.

Eichengreen, B. and Gibson, H. D. (2001), "Greek Banking at the Dawn of the New Millennium”, CEPR Discussion Paper, No. 2791

Heffernan Shelagh (2006),"Modern banking in Theory and Practice", The Wiley Finance series.

Karatzas Committee (1987), "Report of the Commission for the Restructuring and the Modernization of the Greek Banking System" (headed by Th. Karatzas), Hellenic Bank Association, Athens (in Greek).

Noulas, A. (1999), "Profitability and efficiency of the Greek banks (1993-1998), Bulletin Union Greek Banks, Iss. № 4, pp. 53-66.

Serletis, Mishkin (2010),"The economics of money banking and financial Markets" $4^{\text {th }}$ Canadian edition, Pearson Education, Inc. 